\title{
Virtual Enterprises: A Mexican Case Study
}

\author{
A. Molina, M. Flores, D. Caballero \\ CSIM-ITESM \\ Ave. Eugenio Garza Sada 2501 Sur \\ Monterrey, N.L. 64849 Mexico \\ +52 (8) 358-2000 Ext. 5115, fax:+52 (8) 328-41-23 \\ email: armolina@campus.mty.itesm.mx
}

\begin{abstract}
Latin American economy is growing fast and national enterprises are looking for new ways of improving their competitive position against international firms, specially Small and Medium Enterprises. The concept of Virtual Enterprises can be a new way to do business and exploit business opportunities for these companies. In this report we will discuss the Framework for Virtual Enterprises developed in the Alfa Project called COSME-GVE (Global Virtual Enterprise) and a case of study will be presented based on experiences of a Mexican Company.
\end{abstract}

\section{Keywords}

\section{Virtual Enterprise, Virtual Industry Cluster, Virtual Enterprise Broker}

\section{INTRODUCTION}

The new global economy is an area of great opportunity for what has been called Virtual Global Businesses (Hagel III and Armstrong 1997). A framework is presented in this paper for conducting global business in a virtual form. The framework consists of three entities: Virtual Industry Clusters, Virtual Enterprise Broker and Virtual Enterprises. Each entity is described in terms of their core products and core processes. Although the concepts have been used before a framework has been created to better understand the relationships among the entities and the conditions necessary for successful business. The paper also describes a case study of a Mexican company of how the concepts developed in the Framework for Global Virtual Business has been exploited to operate a Mexican Virtual Enterprise, special attention is drawn to the Information Model.

The original version of this chapter was revised: The copyright line was incorrect. This has been corrected. The Erratum to this chapter is available at DOI: 10.1007/978-0-387-35390-6_58 


\section{FRAMEWORK FOR GLOBAL VIRTUAL BUSINESS}

There are few documented cases of companies which have successful at creating Virtual Enterprises in a systematic way (Katzy 1997, Kiesel 1997, Linden 1997). Most of these companies have been successful at creating long term co-operations, but not reaching the point were they create and dissolve enterprises according to market demands. The framework proposed by the ALFA Project COSME-GVE (Molina et al. 1997) has three objectives:

- Understanding the three business entities: Virtual Industry Clusters, Virtual Enterprise Broker and Virtual Enterprises, that are the base for Global Virtual Business.

- Definition of core competences, core process and core products of the three business entities of the framework.

- Description of relationships and interaction between the business entities.

The Global Virtual Business environment is composed by the following business entities:

1.- Virtual Industry Cluster (VIC): aggregation of companies from diverse industries, with well defined and focused competences, with the purpose of gaining access to new markets and business opportunities by leveraging their resources.

2.- Virtual Enterprise Broker (VEB): this business entity is responsible for searching opportunities in the global environment and enables the creation of Virtual Enterprises. The Virtual Enterprise Broker performs the processes of partner search and partner selection, and configures suitable infrastructures for VE formation/commitment (physical, legal, social/cultural, information). To achieve its goal the VEB uses the services provided by Virtual Industry Clusters.

3.- Virtual Enterprises (VE): temporary networks of independent companies linked by information technology that share competences, infrastructure and business processes, with the purpose to fulfil a specific market requirement.

In the GVB Framework the three business entities are described in terms of their core products, core process and core competence. For the purpose of this paper and case study the core products and core processes of these entities are described in Table 1. 
Table 1. Core Products and Core Processes of Virtual Industry Cluster, Virtual Enterprise Broker and Virtual Enterprises within the GVB Framework.

\begin{tabular}{|c|c|c|}
\hline & $\begin{array}{l}\text { Core } \\
\text { Products } \\
\end{array}$ & \begin{tabular}{|l|} 
Core \\
Processes \\
\end{tabular} \\
\hline VIC & $\begin{array}{l}\text { - Core Competence } \\
\text { information }\end{array}$ & \begin{tabular}{|c|} 
- Cluster Management \\
- Enterprise Qualification \\
- Cluster Formation \\
- Cluster Marketing \\
- Core Competence Management \\
\end{tabular} \\
\hline VEB & - Virtual Enterprises & \begin{tabular}{|l} 
- Search/Select Business Opportunities (BO) \\
- Identify BO \\
- Analysis of BO \\
- Select BO for exploitation or sale \\
- Search/Select Partners \\
- Analysis of product life cycle \\
- Identify competencies \\
- Match competencies and partners. \\
- Formation/Commitment \\
- VE Partners configuration \\
- VE Infrastructure configuration \\
- VE integration \\
- VE coordination \\
- Business Opportunity Exploitation \\
- Formalization of enterprise \\
- Enterprise creation
\end{tabular} \\
\hline VE & $\begin{array}{l}\text { - End-products } \\
\text { - Enterprises } \\
\text { - Joint ventures } \\
\text { - Long term } \\
\text { cooperation }\end{array}$ & $\begin{array}{l}\text { - Operation } \\
\text { - Global Concurrent Engineering } \\
\text { - Distributed Supply Management } \\
\text { - Global Project Management } \\
\text { - Global Coordination } \\
\text { - Dissolution } \\
\text { - Residual liabilities } \\
\text { - Asset/Equity dispersal } \\
\text { - Plans for long term relationships } \\
\end{array}$ \\
\hline
\end{tabular}


The successful development of the Virtual Operation relies on the existence of appropriate infrastructures. The proposed infraestructures needed for the creation of Virtual Enterprises are discussed within the AVE Case Framework (Goranson 1995):

- Social/Cultural Infrastructure: development of an Entrepreneur Culture in Small and Medium Enterprises (SMEs) in Mexico.

- Legal Infrastructure: the needs for reforms in Government Policies in Mexico

- Physical Infrastructure: creation of adequate telecommunication and information highways.

- Information Infrastructure: development of reliable and accurate industrial databases.

The application of VOs can be seen as a promising approach, since SMEs in Mexico have the opportunity to achieve global markets without loosing their economic independence. Moreover SMEs have their own identity and want to remain in such a way. Cultural infrastructure related to cooperation among partners have been a common practice in companies where the lack of resources has forced them to project and manufacture products in an outstanding creative and innovative manner, sometimes subcontracting, leasing or borrowing resources from other companies to achieve the desired results. These forms of cooperation are not always formalized in the sense of an official collaboration, instead they have been more seen as support among colleagues. Therefore, a must for VO, i.e. cooperation, is an already frequent practice of Mexican companies. However a major problem for the introduction of VE in Mexican SMEs is the lack of entrepreneur culture, companies owners are usually happy with their current success and they are not looking for new business opportunities, some companies are just concentrated in performing everyday operations and there is no vision for the long run. The fact is that SMEs usually are family business where one persons makes all the decisions and there is no strategic plan for business or technology (Molina 1997).

The new economical agreement NAFTA (Canada, USA and Mexico) seems to satisfy the requirements for the development of VE in Mexico in relation to legal infrastructure. However there are still barriers like the one experienced in the communication industry in Mexico, where until January 1997, it was possible for International Telecommunication companies (AT\&T, $\mathrm{MCI}$ to compete for national markets in telecommunication against the government company (Telmex). Nevertheless there are still a lot of regulations in Mexico about international connectivity and government restrictions in the use of telecommunication technologies.

Physical Infrastructure is one of the critical barriers for the implementation of VEs in Mexico, since it depends on a high investment in communication technologies. 
Regarding the Information infrastructure, there is no reliable information about the state of industry, some studies have been carried out to identify Industrial Clusters in Mexico, but the information is not widespread, and sometimes is kept for government policies (Thole 1997). A first effort in Mexico for the creation of an industrial information site is called SIEM (Acronym in Spanish for Information System for the Mexican Industry) which is a Web site where all the Mexican companies are supposed to subscribe. Nevertheless this effort has failed as there is no trust in Mexican government programs.

\section{MEXICAN CASE STUDY: VIRTUAL MEXICAN ENTERPRISE}

Latin America has been recognized to be a growing market which have shown in the last year an economical boom. In Mexico, with NAFTA and its population of nearly 90 Million has been the target of large USA and Canadian investments in the last year. In Mexico opportunities have emerged not only for large multinational corporations, in sectors like automotive, electronics and communication, but to the national suppliers of these companies which has been pushed to fulfill the required standards (e.g. ISO 9000, QS and ISO 14000). The best example is the automotive industry where companies such as Chrysler, Ford, Mercedes Benz and VW have trying to develop complete supply chains with national manufacturers and there are already cars where all components are manufactured by national firms such as: Stratus from Chrysler in Mexico.

In these scenarios of economical grow, the concept of Virtual Organization has an appeal for its development, and therefore the creation of Virtual Enterprises (VE). Opportunities for VE in Latin America will be for all types of companies (large, small and medium enterprises, and high-tech microcompanies), if adequate conditions are set for the creation of this new business opportunity. The sectors that are more suitable for the formation of VE are manufacturing and services, especially tourism, marketing, software, communication, education and information.

The case of study was carried out in the Virtual Mexican Company (VMC), which is a leader manufacturing company with a virtual production structure, this means a line of specialized, exclusive and qualified workshops that give a flexible and efficient focus. Their main specialized areas are : silk screening, metal mechanic, textile operations, plastic injection and ceramic decoration. Their products focus completely on promotional lines, increasing products and services due to market demands. In this case study the Framework for Global Virtual Business described in section 2 will be compared against the operational models of VMC. This comparison will be performed in each on of the elements of the Framework which are: Virtual Industry Clusters, Enterprise Brokers and Virtual Enterprises. 


\subsection{COMPARISON OF GLOBAL VIRTUAL ENTERPRISE FRAMEWORK AND VIRTUAL MEXICAN COMPANY}

An analysis was made to compare the main points between the Global Virtual Business Framework and how VMC works. It is important to mention that although the activities done by VMC are only with local clusters, it is clear that the Framework and the operation of VMC have close similarities. In table 2 the results obtained after the analysis are shown.

Table 2. Comparison between the Global Virtual Enterprise Framework and VMC operation

\begin{tabular}{|c|c|c|c|}
\hline & $\begin{array}{l}\text { Core } \\
\text { Products }\end{array}$ & GVE Framework & Virtual Mexican Company \\
\hline VIC & $\begin{array}{ll}\text { Core } \\
\text { Competence } \\
\text { information } \\
\text { For VMC: } \\
\text { Suppliers } \\
\text { Information } \\
\text { Database }\end{array}$ & $\begin{array}{ll}\text { - } & \text { Cluster } \\
\text { Management } \\
\text { Enterprise } \\
\text { Qualification } \\
\text { - Cluster } \\
\text { Formation } \\
\text { - Cluster } \\
\text { Marketing Core } \\
\text { Competence } \\
\text { Management } \\
\end{array}$ & $\begin{array}{l}\text { Clusters Formation by } \\
\text { manufacturing processes } \\
\text { and products } \\
\text { Partners qualification } \\
\text { using } 4 \text { main variables : } \\
\text { quality, delivery time, } \\
\text { price and frequency of } \\
\text { business } \\
\text { Database creation and } \\
\text { suppliers development }\end{array}$ \\
\hline VEB & $\begin{array}{l}\text { - Virtual } \\
\text { Enterprises } \\
\\
\text { - For VMC: } \\
\text { Formation of } \\
\text { Suppliers } \\
\text { Networks to } \\
\text { satisfy } \\
\text { specific } \\
\text { demand of } \\
\text { products }\end{array}$ & $\begin{array}{ll}\text { Search/Select } \\
\text { Business } \\
\text { Opportunities } \\
\text { - Search/Select } \\
\text { Partners } \\
\text { - } \text { Formation/Com } \\
\text { mitment } \\
\text { Business } \\
\text { Opportunity } \\
\text { Exploitation }\end{array}$ & $\begin{array}{l}\text { - } \begin{array}{l}\text { Searches and selects } \\
\text { partners using standard } \\
\text { classification }\end{array} \\
\text { - Formation commitment } \\
\text { with a legal contract } \\
\text { specifying tasks for each } \\
\text { partner } \\
\text { - Exploitation of business } \\
\text { opportunities by fulfilling } \\
\text { the needs of the market, } \\
\text { specially high volume of } \\
\text { products and short delivery } \\
\text { times. } \\
\text { Creation of process } \\
\text { manuals to standardize } \\
\text { variables }\end{array}$ \\
\hline
\end{tabular}


Table 2. (Continued)

\begin{tabular}{|c|c|c|c|}
\hline VE & $\begin{array}{ll}\text { - } & \text { End- } \\
& \text { products } \\
\text { - } & \text { Enterprises } \\
\text { - } & \text { For VMC: } \\
\text { end-products } \\
\text { and new } \\
\text { suppliers }\end{array}$ & $\begin{array}{ll}\text { - } & \text { Operation } \\
\text { - } & \text { Dissolution }\end{array}$ & $\begin{array}{l}\text { - } \text { Team work } \\
\text { - } \text { Project management } \\
\text { mantributed supply } \\
\text { - VMC searches for long } \\
\text { term partners } \\
\text { - Provides training to } \\
\text { partners } \\
\text { Once business is satisfied, } \\
\text { VMC tries to continue } \\
\text { with good relationships } \\
\text { with the partners }\end{array}$ \\
\hline
\end{tabular}

On the other hand, the three information entities (product, business process and technology) were also studied. VMC has created a classification using these information entities. Aggregation of companies are done based on the products VMC sells to the market and the technologies that are needed to produce them. So VMC needs mainly product clusters and technological clusters. Technological clusters are based on manufacturing processes. Business process are also needed, but the main business processes are performed by VMC, so the use of business clusters is not used frequently. Table 3 shows the elements in each one of the three information entities used by VMC.

\subsection{VIRTUAL INDUSTRY CLUSTERS}

The information about Industrial Clusters used nowadays by VMC was obtained in commerce chambers, government associations and industrial directories. Sometimes VMC has invited companies to collaborate with them using local newspapers. By now, all the information regarding suppliers and virtual industrial clusters is written in an agenda, nevertheless a short term goal is to create an directory using Excel or other database software to put together all this information.

\section{Cluster Formation and Members Classification}

VMC has performed an aggregation of enterprises or virtual industry clusters according to manufacturing process and products. In other words, when a product needs to be manufactured, VMC will search for partners to satisfy all the manufacturing processes needed to produce it.

To select partners in an objective way, VMC classifies members in each cluster using performance variables. The performance variables used to classify members are : quality, delivery time, price and frequency. Table 5 shows this classification. 
Table 3. Information Model structure used by VMC

\begin{tabular}{|c|c|}
\hline $\begin{array}{l}\text { Information } \\
\text { Entities }\end{array}$ & Virtual Mexican Company \\
\hline - Product & $\begin{array}{l}\text { - Party Tents } \\
\text { - Chairs } \\
\text { - Tables } \\
\text { - Freezers } \\
\text { - Decorated Ceramics } \\
\text { - T-shirts and shorts } \\
\text { - Clothing for patio umbrellas } \\
\text { - Key holders } \\
\text { - Pagnets } \\
\text { - Promotion flags } \\
\quad \text { baseball) } \\
\end{array}$ \\
\hline $\begin{array}{l}\text { Business } \\
\text { Processes }\end{array}$ & $\begin{array}{l}\text { - } \text { Marketing } \\
\text { - Product Development } \\
\text { - Process Design } \\
\text { - Logistics (distribution) } \\
\text { - Client Service } \\
\text { - Inventory Control } \\
\end{array}$ \\
\hline - Technologies & $\begin{array}{l}\text { Focused in manufacturing processes } \\
\text { - Graphic arts } \\
\text { - Printing Operations : Pad printing, manual labeling, } \\
\text { computer vinyl lettering and ceramic decals. } \\
\text { - Metal Mechanics : industrial steel tube cutting, micro } \\
\text { wire welding, electronic galvanizing, powder coating. } \\
\text { - Textile operations : industrial cut, item confection } \\
\text { embroidery, vinyl sewing, heat sealing. } \\
\text { - Plastic Injection } \\
\text { - Ceramic Decoration }\end{array}$ \\
\hline
\end{tabular}




\subsection{VIRTUAL ENTERPRISE BROCKERS}

VMC is an enterprise with a virtual production structure, nevertheless it needs to control the processes shown in Table 4 to operate in a successful way.

Table 4. Processes in the Virtual Mexican Company

\begin{tabular}{|c|c|}
\hline Processes & Activities performed \\
\hline $\begin{array}{ll}\text { - } & \text { Product } \\
\text { Marketing and } \\
\text { Sales }\end{array}$ & $\begin{array}{l}\text { The company founds the clients and performs all the } \\
\text { selling operations }\end{array}$ \\
\hline $\begin{array}{ll}\text { - } & \text { Product } \\
& \text { Development } \\
\end{array}$ & $\begin{array}{l}\text { The research, analysis and product design is performed } \\
\text { in the company }\end{array}$ \\
\hline - Process Design & $\begin{array}{l}\text { The sequence of all the manufacturing processes is } \\
\text { specified by the company }\end{array}$ \\
\hline - Logistics & $\begin{array}{l}\text { The company is in charge of all the materials } \\
\text { transportation }\end{array}$ \\
\hline - Client Service & $\begin{array}{l}\text { All the activities involved with the clients are done in the } \\
\text { company }\end{array}$ \\
\hline $\begin{array}{l}\text { - Inventory } \\
\text { control }\end{array}$ & $\begin{array}{l}\text { The inventories and warehouses are controlled by the } \\
\text { company }\end{array}$ \\
\hline
\end{tabular}

\section{Partner Search}

When a necessity needs to be fulfilled, VMC searches for possible partners. These partners need to fulfil some important characteristics :

- Disponibility

- Good price

- Willing to perform long term business

- Constant quality in their products

- Excellent delivery times

At the same time, VMC prefers partners who specialize in an specific manufacturing process. It also offers training to partners, specially to the ones that only work for them is any process. Table 5 describes how VMC classifies its partners. 
Table 5. Variables for partners classification

\begin{tabular}{|l|ll|}
\hline Variables & \multicolumn{2}{|c|}{ Indicator } \\
\hline - Quality & AAA & Very good, it requires few supervision \\
& AA & Good, it requires close supervision \\
& A & Average, requires very close supervision \\
& X & With this company there is no previous experience \\
\hline - Delivery & AAA & Very good, it can deliver urgent tasks, high availability \\
& AA & $\begin{array}{l}\text { Good, usually collaborates with on-line products with } \\
\text { nime }\end{array}$ \\
& A & $\begin{array}{l}\text { Averal delivery time } \\
\text { - }\end{array}$ \\
& AAA & With this company there is no previous experience \\
\hline Price & Very good, VMC can negotiate prices in good and bad \\
& AA & $\begin{array}{l}\text { Situations } \\
\text { Good, but negotiations need to be carried regarding }\end{array}$ \\
& & $\begin{array}{l}\text { manufacturing costs } \\
\end{array}$ \\
& A & $\begin{array}{l}\text { Prices are proposed always by the supplier with no } \\
\text { chance to negotiate }\end{array}$ \\
& X & With this company there is no previous experience \\
\hline Frequency & 1. Works only with VMC \\
& 2. Works with VMC and with other companies \\
& 3. Works with VMC in sporadic cases \\
& 4. Zero activities with VMC \\
\hline
\end{tabular}

\subsection{VIRTUAL ENTERPRISE}

\section{Formation}

After the partners are searched and selected, a contract is performed among them. VMC is responsible of :

- Materials

- Fixing the price

- Fixing delivery times and quality specifications

As it was mentioned, VMC carries out the processes design and the logistics. So when several manufacturing processes are needed to obtain a product, VMC has to transport the semi-finished product from one partner to the other until the product is finished.

Thanks to this new production concept, VMC has been able to create and produce 120 different products. At the same time, VMC focuses in three main processes : product development, process design and marketing. 


\subsection{INFRAESTRUCTURES}

The infraestructures explained in section 4 were also analyzed in this study case. The results of this analysis are the following:

- Social/Cultural Infrastructure: VMC has developed an Entrepreneur Culture, having a virtual production infraestructure and dealing daily with several partners. Nowadays, VMC is carrying out a program to help their partners increase their competitiveness and quality standard and in this way both can benefit. VMC has shown to be an open minded company that trusts and believes in their partners in order to have a successful virtual enterprise.

- Legal Infrastructure: The contracts made among VMC and the members of the different industrial clusters are usually oral. No legal documents are prepared, therefore VMC has to trust in the partners gentlemen agreement.

- Physical Infrastructure: To be able to operate with its virtual infraestructures, VMC communicates with its partners using telephone, fax and radios. These tools have been good enough for the communication among the members.

- Information Infrastructure: VMC has not developed an electronic industrial database. Nowadays they use an agenda containing the main data from partners to contact them to be able to satisfy a business opportunity. Nevertheless, the creation of a formal electronic partners database is one of their priorities. A short term project to be started with the Manufacturing center of the ITESM is to create an electronic database with the information needed to locate all their possible partners in an easy and effective way.

\section{CONCLUSIONS}

Although the activities performed by VMC are local, its main operations showed similarities with the ones described in the Framework. This proved that the Framework for Global Virtual Business is useful to explain the main operations and activities involved in the creation and development of Virtual Enterprises. At the same time, VMC has realized that a virtual production structure helps to produce more volume, satisfy client needs and reduce production costs and lead times.

Other important point that needs to be mentioned is that the development of an Information Model is important to organize all the information needed by the broker, which in this case is always VMC, to select the best partners. The three information entities, products, business processes and technologies were also used by VMC to create the clusters of possible future partners.

Regarding the infraestructures with which VMC operates, it is clear that a special effort has to be made in the legal and information structures. Contracts among partners have to be written (legal) and not oral, and definitely an 
electronic data base has to be created to obtain the right information needed in the right place and in the right time. On the other hand, the social/cultural infraestructure in VMC has broken paradigms shown in latinamerican companies where trust and long relationships with partners are possible but not easily found.

\section{ACKNOWLEDGEMENTS}

The authors want to acknowledge their colleagues of the ALFA Project COSME-GVE especially: Carlos Bremer and Giuliano Macon from USP (Brazil); Prof. W. Eversheim, Martin Walz and Ralf Kaldowski from WZL (Germany). Our gratitute also goes to the following key personnel of VMC in Mexico: Edmundo Maldonado, Engineering Manager, and Jesús Armando Alonso Amarillas General Director and Owner.

\section{REFERENCES}

Hagel III J., and Armstrong A.G., Net gain - expanding markets through virtual communities, Harvard Business School Press, 1997.

Katzy B., Workshop on Global Virtual Enterrpises, WZL, Aachen, June 1997.

Kiesel, Publicity Brochure, 1997, http://www.kiesel.de

Linden F.A., "Wachsen im Netz", Manager Magazin, Juli, 1997, pp. 103-113.

Molina A., Ponguta S., C. Bremer, Eversheim W., "A Framework for Global Virtual Business", accepted for publication in the journal of Agility and Global Competition 1998.

Molina A., Ponguta S, C. Bremer, "An Information Model to Represent the Core Competences of Virtual", Research Report, WZL TH-Aachen, July 1997. 